\title{
South Korea's ASEAN Foreign Policy Overcame Growth Strategy
}

\author{
Kim Han Su \\ Public Policy Department, Mokwon University, Daejeon, South Korea \\ Email: theory80@naver.com
}

How to cite this paper: Su, K.H. (2019) South Korea's ASEAN Foreign Policy Overcame Growth Strategy. Open Access Library Journal, 6: e5544.

https://doi.org/10.4236/oalib.1105544

Received: June 14, 2019

Accepted: July 2, 2019

Published: July 5, 2019

Copyright $\odot 2019$ by author(s) and Open Access Library Inc.

This work is licensed under the Creative Commons Attribution International License (CC BY 4.0). http://creativecommons.org/licenses/by/4.0/

\section{Open Access}

\begin{abstract}
The core of the foreign policy of Moon Jane's government is the foundation of the "Peace Process of the Korean Peninsula". At the center of the system configuration, it starts from East Asia, and the core of East Asia starts from ASEAN. This paper argues that cooperation with ASEAN is important for the completion of the establishment of the "Peace process of the Korean Peninsula". In order to expand cooperation in various fields such as diplomacy and economy, we must overcome obstacles such as re-authoritative coin tendency. The Moon Jane government named it "New Southbound Policy". However, in fact, there have been no cases where past policies have promoted Southbound policy. Therefore, an approach for new policy establishment is needed, and we will present an effort to construct various cooperation programs.
\end{abstract}

\section{Subject Areas}

Politics

\section{Keywords}

ASEAN, Policy Road Map, Community Initiative, Regional Cooperation Program

\section{Introduction}

The biggest task in the international relations of the Moon Jane government is to seek the direction of the diplomatic solution of the peace process on the Korean Peninsula. To a large extent, along with the establishment of the East Asian region, we must maintain a balanced relationship with the four major countries. Recently, China's trade with China has overheated, and while Korea is in an un- 
easy position, it is making every effort to avoid direct confrontation. In February 2019, the Bank of Korea said, "If the US-China trade dispute is prolonged, Korea may be an opportunity to expand trade with ASEAN," a diagnosis has been issued. This is because China's domestic demand-centered growth strategy is further strengthened by the prolonged trade dispute between the United States and China. Also trade with China has declined as a result of a somewhat stagnant cooperation between ASEAN and China. While the possibility of rapid expansion has become uncertain, it is expected that economic cooperation between Korea and Japan, which seeks to diversify the global supply chain, can be further strengthened [1].

ASEAN will continue to manage the South China Sea conflict in the region into a traditional foreign policy issue, and convert it to the Asia-Pacific region in the Middle East region, a central axis of the problem of the traditional conflict between China and Southeast Asian countries such as the Philippines. The New Defense Strategy Guideline has been involved in the South China Sea parties in conflict with each other. In this process, in the Philippines, both Van der Te regimes have been established, changing the alliance relationship with the United States, which has been consistently promoted, and showing a diplomatic course of prosodic tendencies.

\section{Proposed Policy Approach to Overcome Survival Strategies}

Historically, Southeast Asia has been a cornerstone of fierce diplomatic competition before Korea and North Korea join UN in 1991. Since the establishment of the ASEAN, the international community has begun to draw attention as a new cooperation, and has formed a dialogue channel with major countries such as the US, China, Japan, Australia, India, the EU, etc. to enhance bargaining power. Although the 10 ASEAN states have put together a policy of maintaining neutrality collectively as Korea and North Korea's simultaneous training country, the Korean government's cold diplomatic determination is still lacking. The change in ASEAN's position on the Korean Peninsula issue is due to the recognition of the Korean Peninsula issue as a tool of the "Hedging Strategy" in the conflict between the United States and China. In addition to the threats posed by China's rise, ASEAN, which has not yet considered pragmatic aspects, should also consider its relationship with the United States. The South China Sea issue symbolizes these ASEAN dilemmas, and in the last few years, as the differences of views among ASEAN member states have expanded, the realization of the ASEAN Political Security Community has become a serious issue. ASEAN is a very important partner in the field of international development cooperation in Korea. However, the Bojodem collapsing accident of Lao San-he-Jiang, an old man Noi hydroelectric power dam, which occurred on July 23, 2018, gives a lesson as big as the damage. Thirty-nine people were killed, 97 were missing, and about 13,000 were affected. Disasters that occur in the course of development 
cooperation projects through the attraction of private capital should be carefully investigated as well as the causes of accidents and problems in the process of coping. Economically, while Korea has emerged as China's next largest trading partner, Korea has recorded a unilateral trade surplus. Peace, joint prosperity and the reality that people have yet to be established but not found. The re-authorization tendency of the ASEAN countries that has taken place in recent years has become a major obstacle in understanding the ASEAN vision, but the Korean government is silent [2].

We call it "new" southern, but there was no southern policy before. Southeast Asia, as well as during the Cold War, was thought to be the means to dominate the long North-South diplomatic confrontation. In order to make up for this, Chun Doo, who was convicted in the coup, went up to the so-called "Southeast Asia Tour" in 1981 to establish a dialogue relationship with ASEAN, but returned home with no hand. It was because they recognized that they demanded ASEAN's unilateral North Korean accusation in a position of traditional neutrality.

Above all, as major countries such as the United States, Japan and Australia had already formed cooperative relations with ASEAN, Korea could not feel special attraction. Even after establishing a post-Cold War discourse relationship, Korea's large Southeast Asian policy was limited to pursuing economic benefits and keeping abreast of North Korea due to the division of the Korean peninsula. A new approach is needed to take advantage of the meaning of the new South, which had previously had no South policy. The New South Policy came from an extension of the Northeast Asia and Responsible Community concept, but this is no different from the idea of making the ASEAN and India regions the new growth engine. Southeast Asian diplomats and scholars may misinterpret these ideas as a proposal for a new community. At present, the East Asia region manages the cooperation of ASEAN + 3 (Japan, China and Korea), and the East Asia Summit (Asean $+3+$ Australia, New Zealand, India, the United States, Russia), with a focus on ASEAN. In the past, China, Australia, Japan, etc. proposed East Asia cooperation and a community concept that incorporated their respective strategic understanding, but in the end, it was institutionalized mainly in ASEAN [3].

Korea also greatly contributed to the conception and institutionalization of the East Asian community. The Kim Dae Jung government led the formation and operation of the "East Asia Vision Group (EAVG)" and the "East Asia Study Group (EASG)" and solidified the vision and base for East Asia cooperation. Northeast Asia plus responsible community and new South policies that do not mention East Asian cooperation assets can transfer confusion messages with ASEAN countries. Considering the fact that the past Lee Jong-Pak Rui administration concentrated on ASEAN's request for support for North Korean criticism, we have recently made an effort to explain changes in the Korean peninsula situation, present an East Asia peace plan, and appeal for its support is necessary. In addition, with the situation where the United States, China, and Ja- 
pan try to use ASEAN as a friendship channel, Korea's presence for ASEAN is likely to be less than we expect. The cooperation pursued by Korea and ASEAN must be a common cooperative relationship that shares value and norms, under the circumstances that military power and economic power cannot compete with these major countries. The ASEAN Community, launched in 2015, seeks to realize the value of peace, prosperity and progress for the construction of people-centered/oriented communities. These values drive the cooperation of political security, economic, social and cultural fields. The ASEAN, which is composed of small and medium-sized countries, can only be relatively weak in military power and economic power compared to peripheral powers. Nevertheless, ASEAN's role in the regional order in East Asia can play a central role only because of peace policy in the region and trust building among member states.

\section{Conclusions}

ASEAN has presented the vision of the ASEAN Community through the adoption and institutionalization of various roadmaps, which include values such as democracy, legal justice, human rights, joint prosperity, poverty alleviation, poverty and wealth disparities. It is done. The 3Ps we proposed do not reflect these ASEAN realities and intentions. In order for the new South policy to bear fruit, a new approach is needed, including an improvement in the perception of the other party. First, it is necessary to explore the development of long-term relationships through partnership-based mutual recognition and role-giving, rather than looking at ASEAN countries as unilateral benefits or aid targets.

Second, we need to be able to contribute to strengthening physical, human and institutional cooperation through systematic cooperation so that various cooperation programs with ASEAN do not end in segmented cooperation programs. Contributing to this, while focusing on ASEAN-regional cooperation, we need to be able to strengthen ASEAN-Japan cooperation and contribute to the improvement of cooperation in East Asia. Third, we need to reaffirm our vision in the community beyond profit and loss calculation and set this as the ultimate goal of cooperation. The process is to contribute to the construction of the ASEAN community, and one ASEAN human-centered cooperation should ultimately contribute to the construction of the East Asian community. Also, the New Southbound Policy should work in cooperation with middle powers, which can be a starting point to seek a shift to normative politics, in addition to diplomatic diversification in politics with a four-centred power.

\section{Conflicts of Interest}

The author declares no conflicts of interest regarding the publication of this paper.

\section{References}

[1] Korean Trade Newspaper (19.2.18 Day Coverage). 
[2] Korean Defense Research Institute (2011) Military Force and Strategic Trends in Northeast Asia. pp. 43.

[3] New Southern National Policy Task Force Website. http://www.nsp.go.kr/policy/ 